Winter 2014

\title{
Misreading and Mobility in Constitutional Texts: A Nineteenth Century Case
}

Iza Hussin

University of Chicago, hussin@uchicago.edu

Follow this and additional works at: https://www.repository.law.indiana.edu/ijgls

Part of the Constitutional Law Commons, and the International Law Commons

\section{Recommended Citation}

Hussin, Iza (2014) "Misreading and Mobility in Constitutional Texts: A Nineteenth Century Case," Indiana Journal of Global Legal Studies: Vol. 21 : Iss. 1 , Article 6.

Available at: https://www.repository.law.indiana.edu/ijgls/vol21/iss1/6

This Symposium is brought to you for free and open access by the Law School Journals at Digital Repository @ Maurer Law. It has been accepted for inclusion in Indiana Journal of Global Legal Studies by an authorized editor of Digital Repository @ Maurer Law. For more information, please contact rvaughan@indiana.edu.

\section{$\Psi$}

JEROME HALL LAW LIBRARY

$$
\begin{aligned}
& \text { INDIANA UNIVERSITY } \\
& \text { Maurer School of Law }
\end{aligned}
$$




\title{
Misreading and Mobility in Constitutional Texts: A Nineteenth Century Case
}

\author{
IzA HUSSIN*
}

\begin{abstract}
This article explores the case of the adoption of Southeast Asia's first constitution (Johor, 1895) to articulate a fundamental problem of translation-the ambiguity and multiplicity of law's language. Closer attention to this problem helps raise a number of possibilities for rethinking the relationship between law, language, and mobility: firstly, polyphony, dissonance, and divergence in law's language reveals a plethora of political possibilities, audiences, and actors in the making of law; secondly, these ambiguities and multiplicities are integral to law's mobility; thirdly, rather than transmissions of law from center to periphery, law moves in circulations that are iterative, contingent, and patterned. Finally, tracing the movement of law in time and space reveals that each project of translation is also a project of political transformation: as such, analysis of law's translations also requires analyses of how, why, and with whom, law travels.
\end{abstract}

\section{INTRODUCTION}

The sociologist and legal scholar Boaventura de Sousa Santos advocated nearly three decades ago that instead of seeking out "correspondence/non-correspondence" in the study of relations between law and society, "we should substitute the complex paradigm of

* Assistant Professor, Department of Political Science, University of Chicago. This paper represents a distillation of debates and conversations on law's travels during the conference "Regulatory Translations: Expertise and Affect in Global Legal Fields" (Istanbul, May 16-18, 2013), organized by Boğazici University, Indiana Journal of Global Legal Studies, and Rice University, and an analytic bridge between my textual analysis of the Johor Constitution (1895) and a larger project on the travels of law, currently in progress. My deep thanks to Fred Aman, Andrea Ballestero, and Umut Turem for making these initial explorations possible.

Indiana Journal of Global Legal Studies Vol. 21 \#1 (Winter 2014)

(C) Indiana University Maurer School of Law 
scale/projection/symbolisation."1 Our current concern with the issue of translation in law continues in a long tradition of wrestling with the concept. Santos himself, titling his article Law: A Map of Misreading, referenced literary scholar and critic Harold Bloom's A Map of Misreading (1974), in which Bloom argues:

poems . . . are neither about "subjects" nor about "themselves." They are necessarily about other poems ... . A poet ... in consequence, is not so much a man speaking to men as a man rebelling against being spoken to by a dead man (the precursor) outrageously more alive than himself. ${ }^{2}$

Three years before the publication of Orientalism, Edward Said argued that Bloom's contribution served to underline a move already underway in literary studies, away from "the stability of texts and authors" and toward a critical stance on time, authority, and interpretation in the history of culture. ${ }^{3}$ "No text can be complete because on the one hand it is an attempt to struggle free of earlier texts impinging on it and, on the other, it is preparing itself to savage texts not yet written by authors not yet born."4

This move would be further advanced in Orientalism to emphasize ethnicity, religion, empire, and power in the study of text. ${ }^{5}$ In literary, postcolonial, and translation studies, scholars such as Gayatri Spivak would make explicit that translation not only has political freight but can be a politics: first by making the work and agents of translation themselves visible and then by seeking to translate specificities and "disruptive rhetoricity" rather than achieve equivalences of meaning. ${ }^{6}$ For Spivak, "[t]here is a way in which the rhetorical nature of every language disrupts its logical systematicity ... [which] point[s] at the possibility of random contingency, beside language, around language."7 It is against the backdrop of the lineage of this concern with power,

1. Boaventura de Sousa Santos, Law: A Map of Misreading. Toward a Postmodern Conception of Law, 14 J.L.S. 279, 283 (1987).

2. HaRold BloOM, A MAP of MisREading 18-19 (1975).

3. Edward W. Said, The Poet as Oedipus, N.Y. TIMES (Apr. 13, 1975), http://www.ny times.com/books/98/11/01/specials/bloom-misreading.html.

4. Id.

5. See generally EDWARD W. SAID, ORIENTALISM (1978) (surveying the history of western attitudes toward the east and the impact of orientalism on writers, philosophers, and administrators).

6. See Gayatri Chakravorty SpIVAK, OUTSIDE IN THE Teaching MaChINE 202 (Routledge Classics 2009) (1993).

7. Id. at 201-02. 
agency, and history in the study of translation that the rest of this article will engage with the issue of translation in the study of law.

Sousa Santos characterizes Bloom's influence on his theory in two ways-firstly, "[p]oems misread in order to establish their originality, while laws misread in order to establish their exclusivity."8 Each instance of law's misreading assumes its unique position in the normative order and works to forget its relation to preceding laws-a misreading of social as well as historio-legal realities. Secondly, Sousa Santos takes the metaphor of law as map as an analytic tool for discerning the patterns and mechanisms by which law distorts and represents reality. ${ }^{9}$ The spatial paradigm he proposes sees three kinds of distortions in law: that of scale, which requires a decision about levels of detail; that of projection, which requires a decision about center and periphery; and that of symbolization, which requires a decision about signs and meanings. ${ }^{10}$ These lead to an analytic project for law and society studies that Sousa Santos calls "a symbolic cartography of law." 11 This framework presages the spatial turn in social analysis and sketches out a postmodern approach to law.

This article takes on only the first component of this analytic project, using the concept of symbolic cartography of law, as Sousa Santos recommends, as a metaphor. It draws from a larger research project on the travels of law that begins, as we do here, with a particularly productive moment and site of legal experimentation-late nineteenth century Johor, a sovereign state at the southern tip of the Malay Peninsula hemmed in on all sides by British and Dutch imperialism. The Sultan of Johor rose to power in his state through a shrewd balancing of local, regional, and imperial politics; he was also a cosmopolitan actor in a network of diplomacy, contracts, family, and communications whose nodes included Constantinople and Aceh, London and Calcutta, Tokyo and Bangkok, Chicago and New York, Tarim and Cairo. ${ }^{12}$ The Sultan's lawmaking was part of his political and symbolic repertoire: between 1893 and 1895, he adopted both the Ottoman civil code (Medjelle) and a constitution for Johor, strategic moves aimed at consolidating his sovereignty and succession in the context of British imperial pressure. It is to this moment that we can trace the origins of constitutional monarchy across the Malay Peninsula, as well as the language in the Federal Constitution of

8. Sousa Santos, supra note 1 , at 281 .

9. Id. at 282 .

10. Id. at 286 .

11. Id.

12. See Iza Hussin, Circulations of Law: Cosmopolitan Elites, Global Repertoires, Local Vernaculars (unpublished manuscript) (on file with author). 
Malaysia on many subjects, including the privileges of the monarch, the religion of the state, and the position of Malays in the state.

This paper discusses the text of the Constitution of Johor (1895) to show that the founding documents of states were often, by virtue of their multiple sources and authors, always and already texts in translation. Further, it traces the travels of the constitution across a political geography of local, regional, and imperial sovereignties, a geography that included other monarchical systems facing European pressure: Siam, Meiji Japan, Hawaii, and the Ottoman Empire. Mapping the travels of law helps to make visible the politics of law's translations between imperial, state, and local orders and its transformations in scale, projection, and symbolization. Paying particular attention to the work of translation in the making of nineteenth century law helps make legible the role of ambiguity, misreading, and dissonance in the movement of particular kinds of law-in this case, constitutional law-across a wide geographic arena. ${ }^{13}$

\section{LAW AS MisREAdING: POLYPHONY, DisSONANCE, AND DIVERGENCE}

The first constitution in Southeast Asia was adopted in the state of Johor, the southernmost state in the Malay Peninsula, in 1895. The Sultan of Johor, Abu Bakar (1833-1895), ruled over a state whose wealth, geographic location, and political position placed it under constant pressure from British imperialism. ${ }^{14}$ Ailing and fearing for his succession and the sovereignty of his state, in the last year of his life Abu Bakar introduced the Undang-Undang Tubuh Kerajaan Johor

13. This view of law takes on board the mobility encapsulated in concepts of legal transmission, diffusion, and transplant, and acknowledges its debates. See, e.g., ALAN Watson, Legal Transplants: AN APPROACH to CoMPaRATIVE LAW (1974); Duncan Kennedy, Two Globalizations of Law and Legal Thought: 1850-1968, 36 SUFFOLK U. L. REV. 631 (2003); Pierre Legrand, The Same and the Different, in Comparative Legal STUDIES: TRADITIONS AND TRANSITIONS 240 (Pierre Legrand \& Roderick Munday eds., 2003); William Twining, Diffusion of Law: A Global Perspective, 49 J. LEGAL PLURALISM 1 (2004); David A. Westbrook, Theorizing the Diffusion of Law: Conceptual Difficulties Unstable Imaginations, and the Effort to Think Gracefully Nonetheless, 47 HARV. INT'L L.J. 489 (2006). However, the critical emphasis here is on discovering the ways in which law was transformed by its movement; this emphasis avoids legal positivism and requires closer analytic attention to indeterminacy, ambiguity, and unidirectionality.

14. At the end of the nineteenth century the state of Johor, now part of Malaysia, was located between Singapore and the Malay states, both under British control. Johor held vast amounts of mineral and agricultural resources, as well as having strategic value in the region. It was well known that the Sultan used these resources for the political advantage of his state and his dynasty. 
(Laws of Establishment of the Government of Johor).15 What is apparent from the archive of the Johor Constitution is that there were many constitutional texts in the first years of its adoption-at least four identifiably distinct and roughly contemporaneous versions-two in English, one in Malay, and one in Jawi (Malay in Arabic script). These texts do not simply differ in language and printed form; some contain extra paragraphs of content, each carries interpretations that signal subtle differences in political emphasis and meaning, and each was circulated through different networks of local and colonial actors. Each of these texts on its own also contains ambiguities and contradictions, bearing the trace of many authors and translated concepts from many languages.

Here is the first problem with an idea of translation that presumes an original and a translated text-the polyphony of documents such as the Constitution of Johor, from its earliest iterations, indicates not an original text that was then translated into another language, but a process of drafting, borrowing, and echoing that was cosmopolitan, polyglot, and polyphonous from its start. The process of the Constitution's drafting, by British lawyers in Singapore with the help of English-educated court officials like Abdul Rahman Andak, supports this assertion. That the Sultan also had reference to models of constitutions from the Ottoman Empire (1876) and the Meiji Empire (1890), themselves carrying legal content from a variety of sources, also indicates that the text would likely have had influences and inputs in multiple languages and from multiple legal traditions.

The earliest available text is printed in Jawi, Malay in Arabic script. This, presumably, would have been the "official" text (Version 1: Johor State Archive 1895). Next, chronologically, is a Malay typescript copy attributed to State Secretary Abdul Rahman Andak, dated 1898 (Version 2). ${ }^{16}$ A Colonial Office report from 1900 contained an English text that was provided to the Johor Advisory Board in London (Version 3). ${ }^{17}$ Finally, the Johor government printer later also issued an "official" English text, The Law of the Constitution of 1895, including

15. All translations from the Malay are the author's unless otherwise indicated. All contemporary references in English refer to this document as a constitution. The literal meaning of "tubuh" is "body," or to establish. "Kerajaan," derived from the Sanskrit word "raja" (king, ruler), is understood by European translators to mean "government," but the word itself has a long history within Malay political culture. See ANTHONY C. MILNER, KerajaAn: MaLay POLITICAL CUlture on THE Eve of Colonial Rule 114 (Frank Reynolds et al. eds., 1982).

16. AHMAD FaWZI BASRI, JohoR 1855-1917: PENTADBIRAN DAN PERKEMBanganNya [JOHOR 1855-1917: ITS ADMINISTRATION AND DEVELOPMENT] 153 (1988) (Malay.).

17. 1 A COLlection of TREaties and OTHER Documents AFFECTING THE STATES OF MALAYSIA, 1761-1963, at 77 (J. de V. Allen et al. eds., 1981). 
amendments to 1961 (Version 4). ${ }^{18}$ Version 4, printed in English by the government of Johor printer, is headed by the underlined and capitalized word "Translation," indicating that the text from which it was translated was in Malay. 19

In this final English version, Arabic terms were translated literally, rather than idiomatically, from Arabic to English, further underscoring the unfamiliarity of both the translator and the intended reader with Muslim conventions of address. ${ }^{20}$ The Malay texts also contain a profusion of synonyms, translated English legal concepts, and Qur'anic formulations that indicate they, too, were translations, at least in part. The English texts give the impression of being hardly able to contain the requirements of Malay legal meaning; even accounting for the conventions of Malay court documents, the Malay texts are awkward and labored rather than ornate or elegant. ${ }^{21}$ Each of the four texts of the Constitution gives the impression of being a translation, and none read as though they had been written in the language of its conception.

Each text of the Constitution, on its own, is open to multiple readings because of its internal repetitions and echoes; the original purpose of the repetitions and echoes may have been to capture political concepts very much in flux at the end of the nineteenth century. The multiple ways in which the Sultan's status as law-giver is couched in the Preamble alone indicate that there were many ways his sovereignty might have been understood- - "Sovereign Ruler and Possessor," "We, in Our name, and on Our behalf, and for and on behalf of Our Heirs and Successors," and "Sovereign Rulers or Sultans of Johore,"-and many audiences to whom this constitution would have been intended-"this State of Johore and its Dependencies," "Members of Our Council of Ministers, and of Our Council of State and other Chiefs and Elders," "Government, subjects, and inhabitants of Our Country," and "Our State, Country, and people." 22 Later sections emphasize the absolute authority of the ruler, while elaborating upon the role of consultative bodies in government such as the Council of Ministers; Islam is declared to be the religion of the state, and the officers of the state are required to be Muslim and Malay, but all religions are to be allowed to be practiced in peace and harmony. ${ }^{23}$

18. See generally State of Johore, The LAW of the CONSTitution of 1895 (1962) (Malay.).

19. Iza Hussin, Textual Trajectories: Re-reading the Constitution and Majalah in $1890 \mathrm{~s}$ Johor, 41 INDON. \& MALAY WORLD 255, 265 (2013).

20. Id. at 11 n.19.

21. See id. at 12.

22. STATE OF JOHORE, supra note 18 , at 1.

23. Id. at $15-18$. 
We have established so far that that the Constitution was polyphonous (articulated in many voices and many texts) and dissonant (containing ambiguities and contradictions); the four versions of the Johor Constitution were also divergent, carrying different contents and meanings from each other. For example, the Malay copy (Version 2) attributed to Abdul Rahman Andak, the State Secretary and one of its most important Malay drafters, is missing two paragraphs that appear in the English versions, labeled as "Declaration" and "Royal Command," that seem to emphasize a model of enlightened and rational constitutional monarchy. ${ }^{24}$ The Royal Command further elaborates upon the breadth of membership in the state of Johor-"all the subjects of Our State, of all ranks, nationalities, and religions"--before asserting that "it shall be unlawful, unmanly, rebellious and criminal for any person to refuse to acknowledge and neglect to obey it." 25 In the printed Jawi version (Version 1), these missing paragraphs appear but differ in a new way. This text has the last line of the Royal Command carry meanings the English versions do not: the Malay parsing of "unlawful, unmanly, rebellious and criminal" (Versions 3 and 4) is "haram, dayus, derhaka dan berdosa" (Version 1)- "wrongful, corrupt, treasonous and sinful." 26 Not only, therefore, are the four texts not equivalent, they also carry different political and semantic valences: whereas disobeying the Royal Command is a mundane crime in the English version, in the Malay version, the crime is against God as well as the ruler. ${ }^{27}$

In these multiple texts that co-existed as the earliest articulations of the Constitution of Johor, we see the misreadings that Santos has suggested the law must make to establish itself. Santos has argued that the law, to establish its exclusivity, must misread reality in order "to have the monopoly of the regulation and control of social action within its legal territory."28 This requires acts of echoing as well as erasure of the social and normative orders that the law would replace. Yet, the erasure is never complete, not only because of the normative orders that continue to function despite changes at the level of law, but also because the law itself retains traces of its multiple sources and voices. For Spivak, the work of the translator includes attention to the singularity of a narrative voice and that voice's representation of a singular reality; when reading for "disruptive rhetoricity" in the law, the work of the scholar may be to retain an awareness of the multiplicity of voices in these texts and to acknowledge, if not always preserve, their

24. Id. at 2.

25. Id.

26. Hussin, supra note 19.

27. See id. passim, for a detailed discussion of the textual content of these documents.

28. Sousa Santos, supra note 1, at 281-82. 
polyphony. ${ }^{29}$ The polyphony, dissonance, and divergence of these texts calls into question the myth of a unitary and sacrosanct constitution, even at the moment of founding. ${ }^{30}$

The challenge of reading through the process of law's translations may include attention not only to the politics and logics these multiple voices represented for their times and places, but also to the potential they continue to hold for politics in the future. In Johor, the introduction of the Constitution and the occasions of its translation retained the possibility of multiple political and legal meanings across a range of documents, projecting many visions of politics, legitimacy, and order to appeal to diverse constituencies. These documents also provided an expanded legal lexicon across which later Malay elites would draw. ${ }^{31}$ The promulgation of one of these versions of the Constitution as official law in Johor did not prevent these multiple versions from continuing to exist and exert influence as sources of law for the Federal Constitution of Malaya (1957). The existence of multiple versions of the constitutional text in archives and in legal texts indicates that other Malay rulers who adopted constitutions after 1895, and Malay elites considering a federal constitution in the middle of the twentieth century, had a range of texts from which to choose.

\section{MisReading as MoBILITY: GLOBAL CRISeS, LoCAL CONSTITUTions}

Reading the texts of the Johor Constitution together allows a closer exegesis of law's capacity to misread and to be misread and makes clear how both these capacities for misreading are integral to law's production and its translations. The making of a law, like the making of a poem, involves deep reflexive and historical work-to paraphrase Said's review of Bloom, no law can be complete, because, on the one hand, it is an attempt to struggle free of earlier laws impinging on it, and, on the other hand, it is preparing itself to savage laws not yet written by authors not yet born. ${ }^{32}$ The traces of other laws and other histories remain in the texts of the Johor Constitution, and investigating the circumstances of their origin reveals not a single

29. See SpIVAK, supra note 6, at 202-03.

30. See Hussin, supra note 19.

31. See generally Michael Laffan, Dispersing God's Shadows: Reflections on the Translation of Arabic Political Concepts into Malay and Indonesian, MaLAY CONCORDANCE PROJECT, http://mcp.anu.edu.au/papers/laffan_apc.html (last visited Sept. 11, 2012) (arguing that the translation of political concepts into Malay expanded the range of meanings available to Muslim elites, who chose among multiple registers and genres of text from which to draw their vocabularies).

32. Said, supra note 3. 
original text, but a multiplicity of texts. The polyphony, dissonance, and divergence of legal texts make space for new kinds of political and legal maneuvers and are the very engine of law's mobility. This next section will briefly show the local and global vectors of transformation that may have been at work during Abu Bakar's time-in particular, nascent varieties of Western imperial power and Islamic institutions as symbolic counters to them-to arrive at a better understanding of the mechanisms of "scale/projection/symbolisation" that Santos proposes. ${ }^{33}$

At the end of the nineteenth century, the issues that Abu Bakar of Johor faced were familiar to a number of rulers and states across the globe: In Hawaii, King David Kalakaua faced the threat of annexation and deposition by the United States; ${ }^{34}$ in Japan, pressure from the United States and European imperial powers to open the Japanese economy to outside trade sparked domestic upheaval and attempts to restore the strength of the state; ${ }^{35}$ in the Ottoman Empire, imperial reform efforts were spurred by a need to maintain the standing of the empire against Europe and retain its hold over its territories. ${ }^{36}$ Abu Bakar, a marginal figure in this global drama, nonetheless came into contact with all these systems and their rulers-all sovereigns traversing a global network of diplomacy and cosmopolitan elite culture at a time of great imperial pressure. In the decade before the adoption of the Johor Constitution, Abu Bakar came into contact with multiple experiments and models in constitutional monarchy, all of which worked to strike an increasingly fine balance between the prerogatives and power of the ruler and that of his subjects and servants.

In 1881, King David Kalakaua of Hawaii (reigned 1874-1891) visited Johor on a royal tour around the world that also included the United States, Japan, China, Siam, Burma, India, Egypt, Europe, and the United Kingdom. In Johor, Kalakaua and Abu Bakar found much in common. Kalakaua and Abu Bakar both were world travelers, both seasoned diplomats, and both recognized in each other a common problem-their wealth and the strategic position of their states made them ideal targets for imperial encroachment. ${ }^{37}$ Kalakaua, like Abu Bakar, held his position despite a contested succession and a number of

33. Sousa Santos, supra note 1 , at 283.

34. See Noenoe K. Silva, Aloha Betrayed: Native Hawaitan Resistance to AMERICAN COLONLALISM 123-63 (2004).

35. See generally Tom Ginsburg, The Meiji Constitution: The Japanese Experience of the West and the

Shaping of the Modern State, 34 J. JAPANESE STUD. 505 (2008).

36. See C.V. Findley, Medjelle, Encyclopaedia of Islam, Second Edition, BRILLONLINE REFERENCE WORKS, http://www.encquran.brill.nVentries/encyclopaedia-of-islam-2/medjell e-SIM_5107 (last visited May 6, 2013).

37. See SILVA, supra note 34, at 123-63. 
local competitors, some supported by foreign interests. For both, the question of stability of succession was paramount, as was the need to balance local and imperial politics. By the 1890s, however, Kalakaua had become a model to avoid; forced to sign an 1887 constitution based on the United Kingdom model that greatly diminished his power and disenfranchised most of his subjects, the last King of Hawaii died in San Francisco in $1891 .{ }^{38}$

In 1883, Abu Bakar visited Japan and was the first Asian ruler to be granted an audience with the Meiji Emperor. ${ }^{39}$ Two years earlier, the Emperor had announced his plan to grant representative government to his people, and, at the time of Abu Bakar's visit, an overseas mission was under way to investigate constitutional models for Japan. ${ }^{40}$ The mission having rejected the United States, British, French, and Spanish models, the Meiji Constitution of 1890 drew heavily upon the German model. The Meiji Constitution consolidated the power of the Emperor and strengthened the administration and government in the face of pressures for liberalization and democratization but did so "in a Eurocentric international order by giving the state a European form." 41 This Constitution, and the short-lived Tanzimat Constitution of 1876 (in the Ottoman Empire), were the first in Asia and would be followed by the Johor Constitution in 1895. Both the Tanzimat and the Meiji Constitutions worked to stave off European imperial pressure through a strategy of controlled Europeanization; both worked to weigh the balance of power between monarchy and populism in favor of the throne, along the Prussian model. ${ }^{42}$

38. 4 Hawailan National Bibliography 1780-1900, at 232 (David W. Forbes ed., 2003).

39. Michiko Nakahara, Modern Japan in Asia: Meiji Japan in the Eyes of the Maharaja Abu Bakar, 16 WASEDA J. ASIAN STUD. 15, 15 (1994).

40. While in Japan, Abu Bakar attended the state funeral of Iwakura Tomomi, who had been a powerful advocate of constitutionalism and limited representative government. Id. at 21. While there are no records to show that Abu Bakar discussed a constitution while in Japan, the conjunction of the Iwakura funeral and the overseas mission to research constitutional models for Japan indicate that the subject would have been a matter of some importance for Japanese elites at the time of the visit.

41. Tom Ginsburg, The Meiji Constitution: The Japanese Experience of the West and the Shaping of the Modern State, 34 J. JAPANESE STUD. 505, 507 (2008) (book review). See generally TAKII KAZUHIRO, THE MEIJI CONSTITUTION: ThE JAPANESE EXPERIENCE OF THE WEST AND THE SHAPING OF THE MODERN STATE (David Noble trans., International House of Japan 2007).

42. See Tilmann Röder, The Separation of Powers: Historical and Comparative Perspectives, in ConstiTutionalism IN ISLAMIC COUNTRIES: BETWEEN UPHEAVAL AND CONTINUTTY 321, 321-22 (Rainer Grote \& Tilmann J. Röder eds., 2012); NATHAN J. BROWN, CONSTTTUTIONS IN A NONCONSTITUTIONAL WORLD: ARAB BASIC LAWS AND THE PROSPECTS FOR ACCOUNTABLE GOVERNMENT 21 (2002). 
It is hard to know what models Abu Bakar may have encountered along the way to adopting the Johor Constitution; he certainly did not draft the Constitution himself, relying instead upon English lawyers and close Malay advisors to do so. However, his itinerary in the decade before the promulgation of the Constitution is at least suggestive of his exposure to currents of thought and debate on constitutions and state reform. Certainly, the parallels between the states of Johor and Hawaii, Japan, and the Ottoman Empire would have been a matter of discussion on these trips. When Abu Bakar visited Japan in 1883, he attended the state funeral of Chancellor Iwakura Tomomi, an instrumental figure in ongoing efforts to draft a Japanese constitution. ${ }^{43} \mathrm{He}$ would also later have been aware of an attempt to introduce a constitution in Siam in 1885, a proposal put forward by Siamese elites in Europe and rejected by King Chulalongkorn. ${ }^{44} \mathrm{He}$ visited Germany in 1890, one of several tours to Europe and the United Kingdom.

By the time Abu Bakar arrived in Constantinople in 1893, he, or his advisors and lawyers, would likely have learnt of the suspension of the Tanzimat Constitution by Sultan Abdulhamid II in 1878, particularly because Ottoman law would soon play a large role in Johor's development. After this visit to Constantinople, Abu Bakar introduced

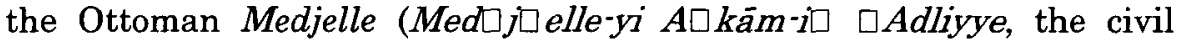
code applied in the Ottoman Empire since 1877) to Johor. ${ }^{45}$ It is in this context that the promulgation of the Constitution, two years later, should be understood, in terms of a program of overarching reform that included legal borrowings and translations. Law was part of the Sultan's repertoire for consolidating his authority and succession, forestalling British imperial encroachment, and developing an administration and bureaucracy through which the ruler would exercise power. Whereas for the Ottomans, the Medjelle represented a reform compromise between advocates of westernization and those who wished to maintain the shari'ah foundations of the law, in Johor the adoption of the Medjelle was an explicitly Islamizing reform that concentrated administrative and interpretive power in the hands of the state. Nowhere is this clearer than in the issue of translation-the Medjelle was not translated from Arabic to Malay in Johor until two decades after its adoption. When printed in Malay for the first time in 1913, the Undang-Undang Sivil Islam: Majalah Ahkam Johor began with the phrase: "This book contains discussions of the fiqh rulings emanating from the shari'ah of Islam used by the government of Johor in times

43. Nakahara, supra note 39 , at 21.

44. See Chris Baker \& Pasuk PhongPaichit, A History of Thailand 76-77 (2005).

45. In this article, "Medjelle" refers to the Ottoman civil code, whereas "Majalah" refers to the Johor civil code. 
past in the Arabic language."46 During the period between the adoption of the Medjelle and its translation, administrative bodies like the Department of Religion and Education were established that bureaucratized Islam and Muslim life further, brought it under the formal purview of the state, and subordinated it to the Constitution. 47

Each of these vignettes above illustrates rulers grappling with the local and global implications of imperial pressure from Western powers and provided, for Abu Bakar, important object lessons about the impact of his choices in the last years of the nineteenth century. The Constitution of Johor carries the traces of Abu Bakar's encounters with many possible variations of constitutional monarchy, all of which sought to consolidate local sovereignty within the context of new imperial hierarchies. These imperial hierarchies provided the discourses by which new constitutional monarchies would articulate their legitimacy; their looming presence in each of these regions was a key impetus driving the pace of legal change, and their expertise and political influence predetermined some of its institutional forms. Yet, Abu Bakar's adoption of the Medjelle shows that Western imperial hierarchy was not the only governing reality that mattered. The forms and symbols of Islam, and of affiliation to the Ottoman Empire, could play an important role both at home and abroad, consolidating dynastic succession and the legitimacy of the state while signaling Johor's continuing independence from the British.

Tracing Abu Bakar's movements across this terrain reveals an ongoing circulation of legal ideas, actors, and institutions. To Santos' spatial model of law's misreadings, therefore, we can add something new about law's movements-they are iterated, cumulative, and circulatory. Thinking about law in circulation in this way helps emphasize not just translation in law's movements but transformations that depend upon political interests, local vernaculars, and contingent configurations of actors and institutions.

\section{CONCLUSION}

By seeking a spatial cartography of law, Sousa Santos makes the spatial and historical implications of law's misreadings clear and draws attention to the fact that these misreadings are often patterned and systematic. As this article has discussed, returning to an emphasis on the ways in which translations move; the actors who carry them across;

46. UNDANG-UNDANG SIVIL ISLAM: MAJALAH AHKAM JOHOR (1913).

47. See generally ABDUL JaLIL BORHAM, MAJALAH AHKAM JOHOR: LATAR BELAKANG, PELAKSANAAN, DAN KOMENTAR [MAJALAH AHKAM JOHOR: BACKGROUND, APPLICATION AND COMMENTARY] (2002) (Malay.). 
and the networks, economies, and politics that bring them over, may provide new insight into law itself, into the work that law does as well as the work that must be done to make the law and continually maintain the law. Paying particular attention to law's movements makes clear the work that must be done to make law's meanings, to convey its local as well as its universal relevance, and to tease out of law's polyphony a particular rule and interpretation. Conversely, paying attention to law's translations helps to clarify that it is the ambiguity, the contradiction, and the multiple nature of law's language that makes this mobility possible. This mobility was neither smooth nor uniform, but critically implicated in diplomatic networks, family connections, and contingent meetings. Each translation-in space as well as in meaning-was motivated by local, regional, and global politics and economics, and had particular nodes, ports of call, and chronologies.

Johor was one of many states in the late nineteenth century facing challenges from Western imperialism and internal political change, and, in his travels, Sultan Abu Bakar found common cause with rulers in Hawaii, Siam, Japan, and the Ottoman Empire. The constitutional solution he implemented in Johor, while it carried elements of each of these encounters, was unique. Its major achievement in its time was the entrenchment of Abu Bakar's succession and the sovereignty of his line in the face of British imperialism and local competitors. However, the inclusion in the Constitution of the institutional underpinnings of consultative government; its articulation of the rights, responsibilities, and limits of sovereign power; and its particular emphasis on Malay and Muslim privilege in state administration would have far-reaching ramifications for later state constitutions and for the Federal Constitution of Malaysia.

To translate means, at its root, to carry across, to bring over; the concept of mobility is inextricable from the more common sense in which translation is used to refer to the conveyance of meaning. ${ }^{48}$ For Bloom and Said, misreading is at the heart of both the making of text and its critique, and the work of misreading that poems and poets do-work that includes forgetting and misremembering the past as well as projecting into an imagined future-is at the core of their originality. For Spivak, a critical stance on translation requires finding the ruptures between the language of a text and its logic, preserving a space for these ruptures, and finding a way to communicate the contingency and personality so often erased in translation. Misreadings are rife in the making of law, and the misreadings that the texts of the Johor

48. See Translate, v., OXFORD ENG. DICTIONARY, http://www.oed.com/view/Entry/20484 1?rskey=idV7j1\&result=2\&isAdvanced=false\#teid (last visited Dec. 5, 2013). 
Constitution represent are many: they misread language; they misread history; they misread religion and race; they misread each of the models on which they may have been based. These misreadings allowed the Constitution to speak to multiple audiences: imperial, Western, Malay, Asian, and Muslim. In their multiplicity, they show that a single reading of law is neither possible nor productive. Quite the opposite, the texts show that seeking out law's polyphony reveals its many authors; listening for law's dissonance makes clear the struggles over which the law barely presides; tracing law's divergences makes visible a number of political possibilities and futures. 